\title{
Oxatomide inhibits Interleukin-8 release from respiratory epithelial cells*
}

\author{
Hideyuki Kawauchi', Noriaki Aoi', Ichiro Morikura', Takafumi Fuchiwaki', \\ Yasuhiko Shimizu', Kanako Shimizu', Yukie Hotta', Qu Infei', Takaya \\ Yamada², Emmanuel Prokopakis ${ }^{3}$
}

Rhinology Online, Vol 1: 50 - 56, 2018 http://doi.org/10.4193/RHINOL/18.026

*Received for publication:

May 25, 2018

Accepted: May 29, 2018

Published: June 6, 2018

2 Department of Experimental Animals, Interdisciplinary Center for Science Research, Organization for Research, Shimane

${ }^{3}$ Department of Otolaryngology, University of Crete School of Medicine, Heraklion, Crete, Greece

\begin{abstract}
Background: Oxatomide, a H1-receptor antagonist, exerts besides its well-known anti-allergic potential an array of anti-inflammatory activities. We wondered whether oxatomide might influence the release of IL-8 from human epithelial cells activated with agonists of TLR2, which mainly expresses on airway epithelial cells.
\end{abstract}

Methodology: We used the human lung epithelial cell line A549 and primary Human nasal epithelial cell line for our in vitro studies. IL-8 releases from these cell lines were determined by IL-8 enzyme immunoassay. NF-кB was analysed by Luciferase reporter assay. Confluent epithelial cell monolayer were pre-incubated with oxatomide for $30 \mathrm{~min}$ and afterwards activated with lipoprotein as a TLR2 agonist for $24 \mathrm{~h}$.

Results: Epithelial cells stimulated with lipoprotein showed a significantly increased release of IL-8. Pre-incubation with oxatomide diminished the IL-8 release from cells activated with lipoprotein in a significant manner. Furthermore, activity of the NF- $\kappa B$ was determined by luciferase reporter assy. Besides, oxatomide inhibits expression of MIP2, a homologue of human IL-8, and neutrophilic infiltration in nasal membrane of mice intranasally exposed with lipoprotein. These results suggest that oxatomide reduced the release of IL-8 from respiratory epithelial cells stimulated with lipoprotein.

Conclusion: Therefore, oxatomide might exert anti-inflammatory effects beyond its $\mathrm{H} 1$-receptor antagonistic activity in the course of inflammatory respiratory tract disorders such as acute bacterial rhinitis.

Key words: $\mathrm{H}_{1}$-receptor antagonists, IL-8, nasal epithelial cell, NF-KB

\section{Introduction}

Oxatomide, a carboxylated metabolite of hydroxizine, belongs to the new generation of $\mathrm{H} 1$-receptor antagonists ${ }^{(1)}$. A positive therapeutic effect of oxatomide has been shown in allergic rhinoconjunctivitis, chronic urticaria, and pollen-associated asthma $(2,3)$. There has also been an accumulation of evidence that oxatomide shows some anti-inflammatory activities unrelated to its histamine antagonism, e.g. the chemotactic activity of granu- locytes, T cells ${ }^{(4)}$ and the adhesion of eosinophils to endothelial cells was inhibited ${ }^{(5)}$. It has been shown that the production of newly generated pro-inflammatory mediators such as reactive toxic oxygen radicals and lipid mediators from eosinophils ${ }^{(6)}$, basophils and mast cells ${ }^{(7)}$ was counter-regulated by oxatomide. Besides, LTD4 in middle ear of chinchillas with otitis media with effusion was reported to be suppressed by oxatomide ${ }^{(8)}$. It has also been shown that epithelial cells play a crucial role during

Abbreviations used in this paper: IL, Interleukin; CD, Clusters of differentiation; TRL, Toll-like receptor; FCS, Fetal calf serum; HNECs, Human nasal epi-

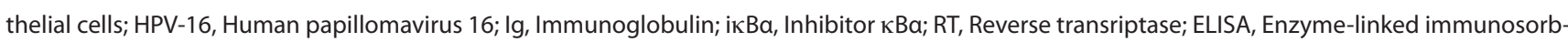

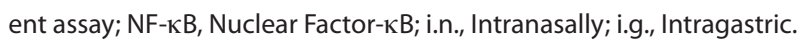


acute inflammatory and infectious processes by secreting interleukin-8 (IL-8) ${ }^{(9-12)}$. The multifactorial pro-inflammatory cytokine IL-8, a member of the chemokine super-gene family ${ }^{(13)}$, has chemotactic activity toward neutrophils as well as T lymphocytes ${ }^{(14)}$. In addition, neutrophils are activated by IL8,enhanced expression of Clusters of differentiation (CD) 11b/ CD18, transendothelial migration, generation of reactive oxygen products and exocytosis ${ }^{(15)}$. As a direct consequence of this potent neutrophil-activating potential, IL-8 plays a major role in the pathogenesis of many acute inflammatory reactions, including acute rhinitis ${ }^{(16,17)}$. Epithelial cells recognize microbial pathogens by a set of germ line-encoded receptors that are referred to as pattern-recognition receptors. Toll-like receptors (TLRs) function as the major epithelial pattern-recognition receptors in recognition of a pathogen-associated molecular patterns ${ }^{(18)}$. Activation of TLRs, in turn, leads to induction of direct antimicrobial effector pathways that can result in elimination of the invading pathogens ${ }^{(19)}$. Activation of TLRs also induces the expression of co-stimulatory molecules and the release of IL-8 that instruct the acquired immune response ${ }^{(20)}$. To date, 10 members of the human TLR family have been cloned. Among these, TLR2 has been shown to mediate responses to a variety of Gram-positive products, including peptidoglycan, lipoprotein, lipoteichoic acid and lipoarabinomannan. It is clear that TLR2 plays a crucial role in host defense against both Gram-positive and -negative bacteria ${ }^{(21,22)}$. Interestingly, in the upper respiratory tract, it has been reported that TLR2 is expressed dominantly in epithelial cells ${ }^{(23)}$. We wondered whether IL-8 production by human epithelial cells stimulated with lipoprotein via TLR2 might also be influenced by the $\mathrm{H} 1$-receptor antagonist oxatomide. We used the human pulmonary type II epithelial cell line A549 and primary Human nasal epithelial cells (HNECs) for our in vitro study. We also assessed the in vivo role of oxatomide in a murine acute rhinitis model.

\section{Methods}

\section{Reagents}

Synthetic Lipid A was provided by Ono Pharmaceutics. Synthetic lipoprotein (palmitoyl-Cys(RS)-2,3-di(palmitoyloxy)-propyl)-AlaGly-OH)) was provided by Bachem (Bubendorf, Switzerland).

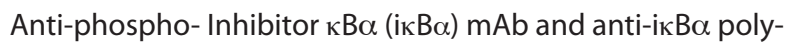
clonal Ab were obtained from New England Biolabs (Beverly, MA, USA) and Santa Cruz Biotechnology (Santa Cruz, CA, USA), respectively. Anti-murine MIP-2 monoclonal antibody was purchased from Genzyme-Thecne (Techne, AN'ALYZA immunoassay system; Genzyme).

\section{Cells}

Cells of the human A549, pulmonary epithelial cell line (ATCC CCL 185, Rockville, MD, USA) show features of type II alveolar epithelial cells and produce surfactants ${ }^{(24)}$. The cells were grown in FK12 medium containing 10\% (v/v) fetal calf serum (FCS), 100 $\mu \mathrm{g} / \mathrm{ml}$ streptomycin, $100 \mathrm{IU} / \mathrm{ml}$ penicillin and $20 \mathrm{mmol} / \mathrm{l}$ sodium hydrogen carbonate. Normal human nasal tissues $(500 \mathrm{mg}$ ) were obtained from two patients with chronic sinusitis after receiving informed consent from the patients. HNECs were transfected with human papillomavirus 16 (HPV-16) E6 and E7 open reading frames. These cells were designated HNEC- 1 and HNEC-2, respectively, and used between passages 50 and 60 . HEK293 and U937 as a human monocytes were obtained from ATCC.

\section{Cell culture conditions}

A549 cells, HNEC- 1 and HNEC- 2 were cultured at $37^{\circ} \mathrm{C}$ in a watersaturated atmosphere containing $5 \% \mathrm{CO}_{2}$. Only cell preparations with a viability greater than $95 \%$, determined by a trypan blue exclusion test, were used. The buffers and cell media were prepared using pyrogen-free water. Confluent A549, HNEC-1 and HNEC-2 monolayers ( $10^{5}$ cells) were cultured in $1 \mathrm{~mL}$ RPMI-1640 $(10 \% \mathrm{FCS}[\mathrm{v} / \mathrm{v}])$ with antibiotics in 24-well plastic tissue culture plates (Costar, Cambridge, MA, USA). Confluent monolayers were pre-incubated with oxatomide $(0.01-10 \mu \mathrm{g} / \mathrm{ml})$ for $30 \mathrm{~min}$. After pretreatment, the cells were washing with PBS twice. The range of doses used, $0.01-10 \mu \mathrm{g} / \mathrm{ml}$, corresponds to the physiological plasmatic concentration range of oxatomide. After $24 \mathrm{~h}$ of culture, the cell supernatants were collected and stored at $-70^{\circ} \mathrm{C}$ until IL-8 determination.

\section{Mice}

C57BL/6 mice were purchased from Japan SLC (Shizuoka, Japan). The mice were bred in our institute under specific pathogen-free conditions. Eight- to 10-week-old female mice were used for the experiments.

\section{Reverse transcription-PCR}

Total cellular RNA from A549, HNEC-1, HNEC-2 and U937 was extracted with RNAzol B (Tel-Test, Friendswood, TX, USA) using a single-step isolation method ${ }^{(25,26)}$ according to the manufacturer's recommendation. RNase-free DNase (Takara Biochemicals, Shiga, Japan) was used to remove genomic DNA based on methods described previously ${ }^{(27)}$. Two micrograms of extracted RNA was reverse-transcribed into first-strand CDNA at $42^{\circ} \mathrm{C}$ for $40 \mathrm{~min}$ using $100 \mathrm{U} / \mathrm{ml}$ of reverse transcriptase (RT) (Takara Biomedicals, Shiga, Japan) and $0.1 \mu \mathrm{M}$ oligo(dT) adapter primer (Takara Biomedicals, Shiga, Japan) in a $50-\mu l$ reaction mixture. PCR amplification of CDNA was performed using oligonucleotide primers specific for TLR1 (Sense: 5'-AGTTGTCAGCGATGTGTTCGG-3' Antisense: 5'-GATCAAGTACCTTGATCCTGGG-3', TLR2 (Sense: 5'-GGCTTCTCTGTCTTGTGACC-3' Antisense: 5'-GGGCTTGAACCAGGAAGAC G-3'), TLR3 (Sense: 5'-AGCCACCTGAAGTTGACTCAGG-3' Antisense: 5'-CAGTCAAATTCGT GCAGAAGGC-3'), TLR4 (Sense: 5'-TTGTATTCAAG GTCT GGCTGG-3' Antisense: 5'-GCAAC CTTTGAAACTCAAGCC-3'), TLR5 (Sense: 5'-AGCCATCTG ACTGCATTAAGG-3' Antisense: 5'-GACTTCCTCTTCAT- 
CACAACC-3'), TLR6 (Sense: 5'-CCTG GGAGGTAAACATCTGA-3' Antisense: 5'-CCCTCAACCACATAGAAACGA-3'), TLR7 (Sense: 5'-GATAACAATGTCACAGC CGTCC-3' Antisense: 5'-GTTCCTGGAGTTTGTTGATGTTC-3'), TLR8 (Sense: 5'-GTGTCACCC AAACTGCCAAGCTCC-3' Antisense: 5'-GATCCAGCACCTTCAGATGAGGC-3'), TLR9 (Sense: 5'-TACCAACATCCTGATGCTAGAC TC-3' Antisense: 5'-TAGGACAACAGCAGATACTCCAG G-3')(28), TLR10 (Sense: 5'-ATGAGA CTCATCAGAAACATTTAC-3' Antisense: 5'-GCGGATCC GCTACCTTCTTCATAATG-3) ${ }^{(29)}$ and $\beta$-actin (5'-GTGGGGCGCCCCAGGCACCA-3' and 5'-CTCCTTAATGTCACGCACGATTTC-3') (30). Five microliters of CDNA from the sample was amplified with 0.2 $\mu \mathrm{M}$ of the sense and antisense primers for the target genes in a $50-\mu$ reaction mixture containing $75 \mathrm{U} / \mathrm{ml}$ of Takara Taq (Takara Biomedicals, Shiga, Japan). After an initial denaturation at $94^{\circ} \mathrm{C}$ for $2 \mathrm{~min}$, various cycles of denaturation $\left(94^{\circ} \mathrm{C}\right.$ for $\left.45 \mathrm{~s}\right)$, annealing $\left(58\right.$ to $60^{\circ} \mathrm{C}$ for $\left.1 \mathrm{~min}\right)$, and extension $\left(72^{\circ} \mathrm{C}\right.$ for $2 \mathrm{~min}$ ) for the respective target genes were performed using a Takara Thermal Cycler MP (Takara Biomedicals, Shiga, Japan). For a negative control, a non-RT sample was amplified by PCR. Following PCR, $10 \mu \mathrm{l}$ of the total amplified product was electrophoresed on ethidium bromide-stained $1.5 \%$ agarose gels and visualized under UV fluorescence. Densitometric analysis of the PCR-amplified bands was performed with NIH Image Software.

\section{Enzyme-linked immunosorbent assay (ELISA) against hu- man IL-8}

The amount of IL-8 released into the cell supernatants was determined by a specific ELISA with a detection limit of $30 \mathrm{pg} / \mathrm{ml}$ as previously described. Briefly, flat-bottomed, 96-well microtiter plates (Nunc Immunoplate I 96-F, Maxisorb, Wiesbaden, Germany) were coated with $100 \mu \mathrm{l} /$ well of mouse anti-IL-8 antibody $\left(5 \mu \mathrm{g} / \mathrm{ml}\right.$ in $0.1 \mathrm{~mol} / \mathrm{l} \mathrm{NaHCO}_{3} / \mathrm{NaCO}_{3}$ buffer, $\left.\mathrm{pH} 9.6\right)$ for $16 \mathrm{~h}$ at $4^{\circ} \mathrm{C}$ and then washed four times with PBS containing $0.05 \%$ Tween 20 (washing buffer). Standards and samples were added as $100 \mu \mathrm{l}$ aliquots in dilution buffer (washing buffer, 2\% FCS) and incubated for $2 \mathrm{~h}$ at $37^{\circ} \mathrm{C}$. Plates were rinsed with washing buffer four times, followed by the addition of $100 \mu \mathrm{l} /$ well alkaline phosphatase-conjugated goat antihuman IL-8 antibody as the revealing antibody ( $5 \mathrm{\mu g} / \mathrm{ml}$ in dilution buffer). The plates were incubated for $2 \mathrm{~h}$ at $37^{\circ} \mathrm{C}$. Thereafter, the plates were washed four times and developed with $100 \mu \mathrm{l} /$ well of the chromogen substrate $\mathrm{p}$-nitrophenylphosphate $(1 \mathrm{mg} / \mathrm{ml})$ dissolved in TRIS/ $\mathrm{MgCl}_{2}\left(0.15 \mathrm{~mol} / \mathrm{l}, 4 \mathrm{mmol} / \mathrm{l}, \mathrm{pH}\right.$ 9.6) buffer ${ }^{(31,32)}$. The plates were read at $405 \mathrm{~nm}$ in an ELISA reader.

\section{Western blot analysis}

Cells were lysed in ice-cold lysis buffer (50 mM HEPES ( $\mathrm{pH} 7$ ), $150 \mathrm{mM} \mathrm{NaCl}, 10 \%$ glycerol, $1 \%$ Triton X-100, $1.5 \mathrm{mM} \mathrm{MgCl}_{2^{\prime}}$ $1 \mathrm{mM}$ EGTA, $100 \mathrm{mM} \mathrm{NaF}, 10 \mathrm{mM} \mathrm{NaPPi}, 1 \mathrm{mM} \mathrm{Na}_{3} \mathrm{VO}_{4^{\prime}} 1 \mathrm{mM}$ PMSF with aprotinin, and leupeptin at $10 \mu \mathrm{g} / \mathrm{ml})$. The lysates $(20$ $\mathrm{mg}$ ) were separated by $10 \%$ SDS-PAGE, and the proteins were

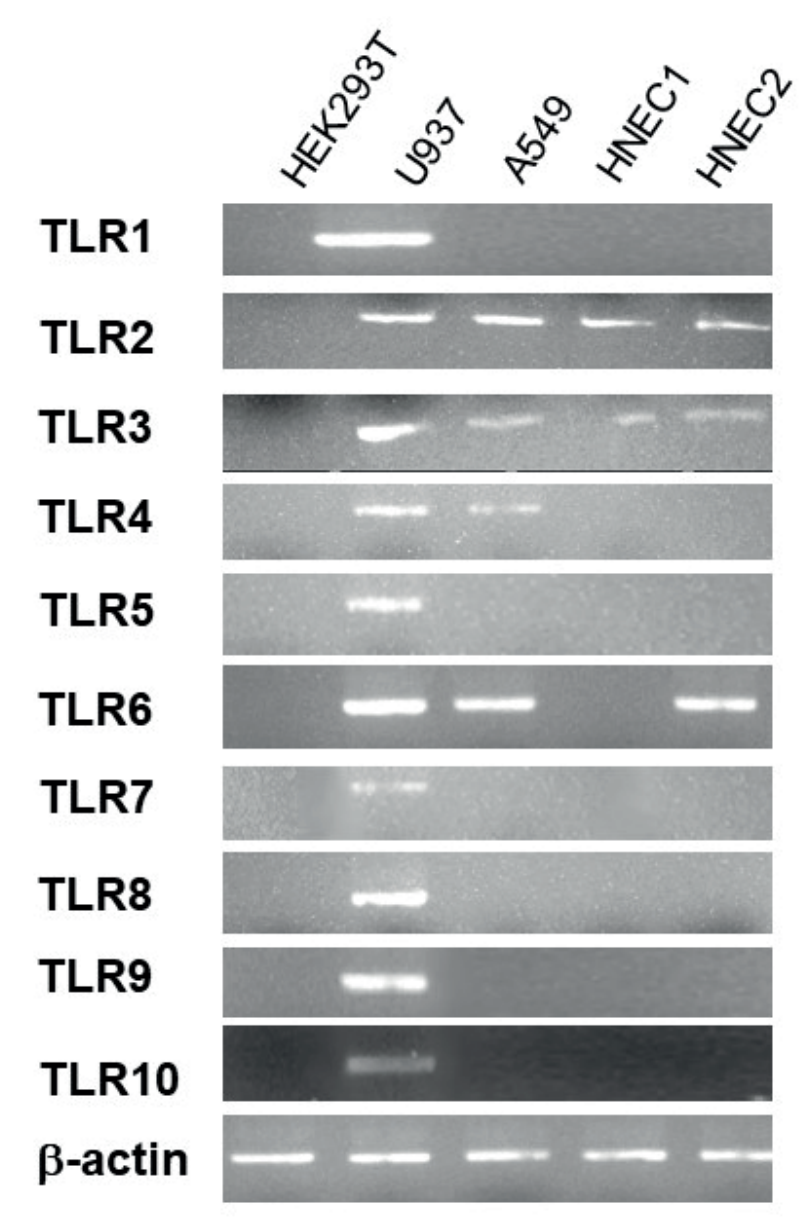

Figure 1. Expression of TLRs in human A549 and HNEC by RT-PCR. Total RNA from both cultured A549, HNEC-1and HNEC-2 were reverse transcribed with an oligo(dT) primer, followed by PCR with primers specific to TLR1 to TLR10, or ß-actin (as a loading control).

transferred to Immobilon polyvinylidene difluoride membranes (Millipore, Bedford, MA, USA). Membranes were blocked with $1 \%$ BSA in TBST for $1 \mathrm{~h}$, and Western blot analysis was performed as described previously ${ }^{(33)}$, followed by detection using an $\mathrm{ECL}$ system (Amersham Pharmacia Biotech, Piscataway, NJ, USA) according to the manufacturer's instructions.

\section{Luciferase assays}

A549 cells were transiently transfected with $2 \mu \mathrm{g}$ of pGL3Nuclear Factor- $\kappa \mathrm{B}(\mathrm{NF}-\kappa \mathrm{B}) / \mathrm{Luc}$ (a luciferase reporter construct containing a consensus NF- $\kappa B$ binding sequence) and $0.2 \mu \mathrm{g}$ of pRL/SV40 (an internal control) by Lipofectamine (Life Technologies) according to the manufacturer's instructions. Twenty-four hours after the transfection, some cells were pretreated with oxatomide or curcumin for $30 \mathrm{~min}$ followed by the addition of $1 \mu \mathrm{g} / \mathrm{ml}$ lipoprotein. After 8-h incubation with lipoprotein, cells were lysed, and the luciferase activity was measured by using a Dual-Luciferase Reporter Assay System (Toyo Ink, Tokyo, Japan) 


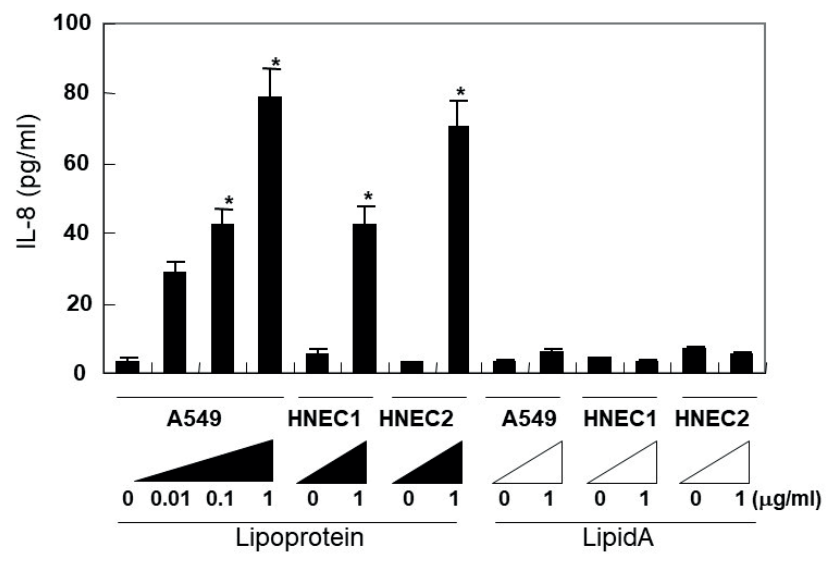

Figure 2. IL-8 release from A549, HNEC-1 and HNEC-2 cells activated with lipoprotein or lipid A. Confluent monolayers were incubated with medium alone (control) or stimulated with lipid $A(0-1 \mu \mathrm{g} / \mathrm{ml})$ or lipoprotein $(0.01-1 \mu \mathrm{g} / \mathrm{ml})$. After $24 \mathrm{~h}$ culture cell supernatants were harvested and analysed for IL- 8 by ELISA. Values are means \pm SEM from three independent experiments and are expressed as nanograms per $\mathrm{mL}$ and $10^{5}$ cells. *P $<0.05$.

according to the manufacturer's instructions. Background luciferase activity was subtracted, and the data are presented as means \pm SD of triplicate samples ${ }^{(34)}$.

\section{Acute rhinitis model}

C57BI/6 mice (females, 6weeks old) were intranasally injected with $10 \mu \mathrm{g}$ of lipoprotein 2 times per day for 2 days. $2 \mathrm{mg}$ of Oxatomide in $200 \mu \mathrm{l}$ of saline was daily inoculated with an intragastric intubation into mice. Twenty four hours after the last injection of lipoprotein, mice were killed and then nasal membrane tissues were stained by the HE-staining method. The counts of neutrophils and macrophages were performed under the light microscope. Then, we collected the lysates from nasal membrane using ice-cold lysis buffer and analyzed the expression of MIP-2 by western blot assay.

\section{Statistical analysis}

The statistical significance of the data was determined by Student's t-test. A value of $p<0.05$ was taken as significant.

\section{Results}

Expression of TLR on respiratory epithelial cells We examined the expression of TLRs mRNA on A549 cells, HNEC1 and HNEC- 2 by RT-PCR. As shown in Figure 1, both A549 cells and HNECs showed TLR2 and TLR3 mRNA expression, however, HNECs expressed no TLR4 mRNA. A549 cells and HNEC1 expressed TLR6 mRNA. But A549 cells and HNECs expressed no TLR9 mRNA. TLR1, TLR5, TLR7, TLR8 and TLR10 mRNAs were also not expressed in A549 cells and HNECs. U937, as a control,

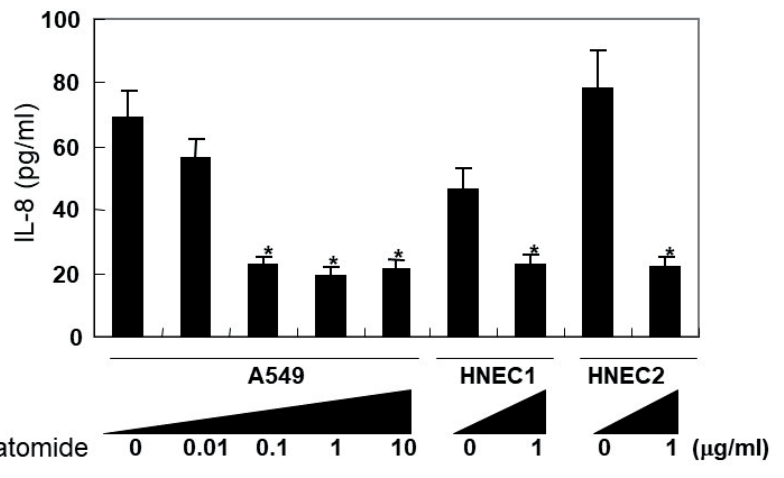

Figure 3. Effects of oxatomide on IL-8 release from A549 and HNECs. Confluent monolayers of A549 or HNECs cells were pre-incubated with oxatomide $(0.01-10 \mu \mathrm{g} / \mathrm{ml})$ or PBS (control) for $30 \mathrm{~min}$ and then activated with lipoprotein $(1 \mu \mathrm{g} / \mathrm{mL})$. ${ }^{*} \mathrm{P}<0.05$.

markedly expressed high level of TLR2, TLR3, TLR4, TLR6 and TLR9 mRNA. RT-PCR analysis of $\beta$-actin expression confirmed the quality of all RNA preparations used for RT-PCR. No band was detected in the non-RT sample by PCR.

\section{Induction of IL-8 production}

IL-8 producing activities in A549 cells and HNECs after stimulation with lipoprotein (as a TLR2 and TLR6 ligand) and lipid A (as a TLR4 ligand) were examined (Figure 2). Lipoptotein significantly induced IL-8 production in both A549 cells and HNECs, whereas stimulation of these cells with lipid A resulted in no induction of IL-8 production.

Effects of oxatomide on IL-8 production by A549 cells and HNECS

As shown in Figure 3, pre-incubation of A549 cells and HNECs with oxatomide in the dose range of $0.01-10 \mu \mathrm{g} / \mathrm{ml}$ significantly diminished the lipoprotein-induced IL- 8 release. The IL- 8 release from A549 cells stimulated with lipoprotein for $24 \mathrm{~h}$ was significantly inhibited by oxatomide even at $0.1 \mu \mathrm{g} / \mathrm{ml}$. Furthermore, the releases of IL- 8 from both HNEC- 1 and HNEC- 2 was also inhibited by pre-treatment with oxatomide at $1 \mu \mathrm{g} / \mathrm{ml}$.

Lipoprotein-induced NF- $\kappa$ B activation may be regulated by oxatomide

To determine whether the inhibitory effect of oxatomide on IL-8 production correlated with the inhibition of NF-KB activity, we performed a luciferase reporter assay. A549 cells were transfected with a luciferase reporter construct containing an NF- $\kappa B$ recognition sequence and then treated with oxatomide and lipoprotein. As shown in Figure 4A, concentration-dependent inhibition of NF- $\kappa B$ activity by oxatomide correlated well with the inhibition of IL-8 production, suggesting that NF-KB inhibition may be essential for the regulation of lipoprotein-mediated IL-8 
A

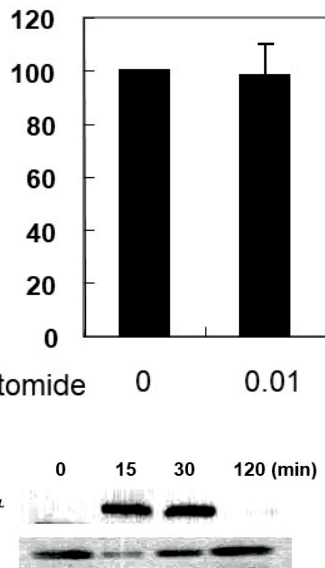

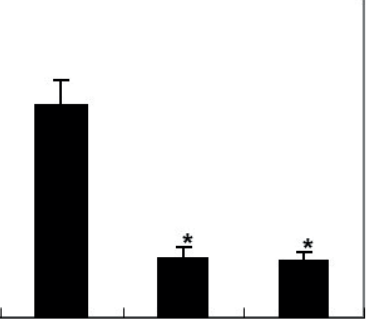
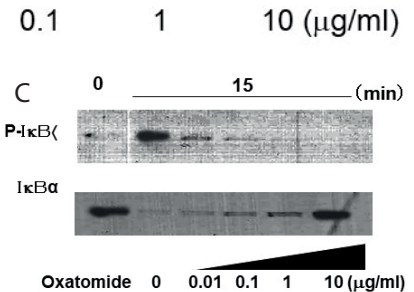

Figure 4. Inhibition of lipoprotein-mediated NF-KB activation and phospholylation of iKBa by oxatomide in A549. A) A549 cells were transiently transfected with an NF- $\kappa B$ reporter plasmid along with an internal control. At $24 \mathrm{~h}$ after the transfection, the cells were pretreated with various concentrations of oxatomide for $30 \mathrm{~min}$ followed by $1 \mathrm{ng} / \mathrm{ml}$ lipoprotein stimulation. Cells were lysed after the 8-h lipoprotein treatment, and the standardized luciferase activities were measured. The assay was repeated three times. The luciferase activity for lipoprotein treatment alone was defined as $100 \%$ in each experiment. Results are presented as mean \pm SD. B) Time course analysis of $I \kappa B \alpha$ subunits and phospholylation of I $\mathrm{K} \mathrm{\alpha} \alpha$ in $\mathrm{A} 549$ stimulated with lipoprotein as detected by Western blot. Results from one representative experiment are shown. C) Analysis of oxatomide on degradation of $1 \kappa B \alpha$ and phospholylation of $1 \kappa B \alpha$ in A549 after stimulation with lipoprotein. Oxatomide was added 30min before stimulation with lipoprotein.

production by oxatomide. We then analyzed the effects of oxa-

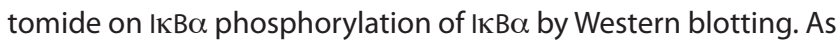
shown in Figure $4 B$, I $\kappa \alpha$ was significantly phosphorylated by lipoprotein $15 \mathrm{~min}$ after stimulation with lipoprotein. However, in the case of pretreatment with oxatomide, phosphorylation of I B $\alpha$ was markedly inhibited even at $0.01 \mu \mathrm{g} / \mathrm{ml}$ (Figure $4 \mathrm{C}$ ). These data corelate with results of the luciferase assay.

In vivo role of oxatomide on in a murine acute rhinitis model To determine the effects of oxatomide on acute rhinitis, we established a murine acute rhinitis model. C57BI/6 mice were intranasally (i.n.) injected with lipoptotein for 2 days. After intranasal injection, the skin around the nose was severely inflamed (Figure 5A). Neutrophil infiltration was clearly observed in the nasal membrane (Figure 5B). MIP-2, a homologue of human IL-8, expressed in the nasal membrane compared with naive mice (Figure 5C). In contrast, intragastric (i.g.) inoculation of oxatomide inhibited nasal skin inflammation and neutrophil infiltration (Figure 5A and B ). Interestingly, MIP-2 expression was also inhibited by i.g. inoculation of oxatomide.
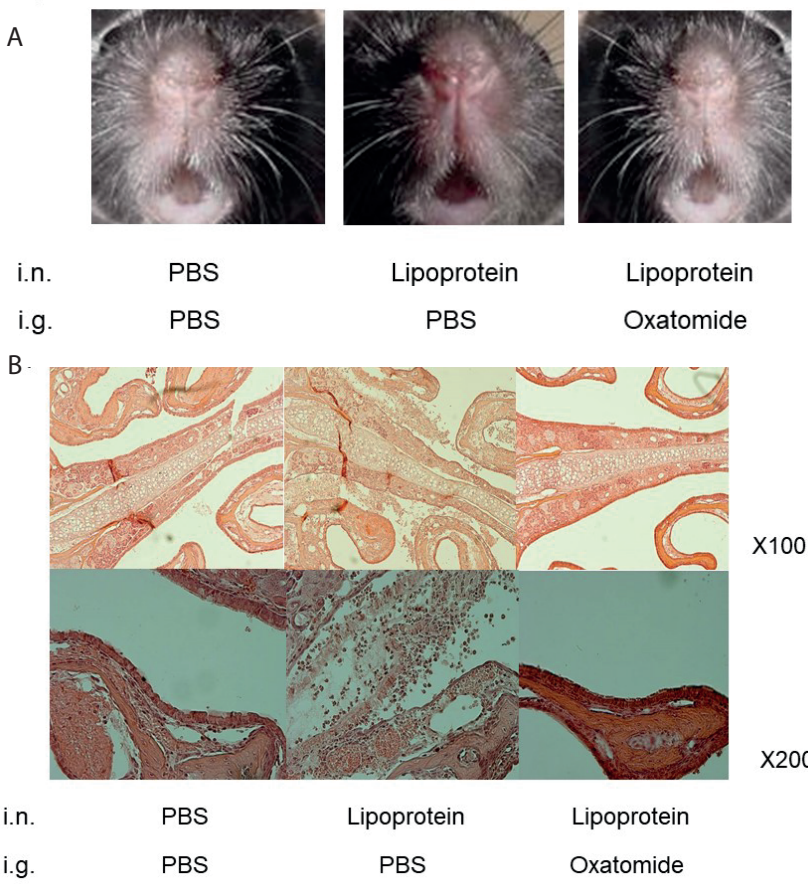

C Mip-2

i.n. i.g.
PBS PBS

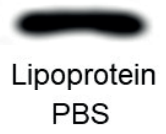

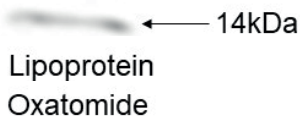

Figure 5. Effects of oxatomide on murine acute rhinitis model. C57BL6 mice were i.n. exposed to lipoprotein for 2 days. A) Photograph of murine face skin around anterior nasal foramen. Left: naive mice. Middle: Lipoprotein exposed mice. Right: Oxatomide-treatment mice exposed with Lipoprotein. B) Nasal membrane tissues of inferior turbinate stained with $\mathrm{HE}$ staining method. C) Expression of MIP-2, IкB $\alpha$ and phosphoIylated-I $\mathrm{B} \alpha$ in nasal tissue of mice by western blott assay. Lysate (20 $\mathrm{mg}$ ) from the nasal membrane were loaded. Data shown represent one of the triplicate experiments.

\section{Discussion}

Acute nasal inflammatory diseases are infectious, have a bacterial etiology, and cause inflammatory responses elicited by nasally pathogenic exposure. In these responses, nasal epithelial cells are thought to play important roles as the initial point of contact with pathogens. It has been shown that the extravasation step of neutrophil granulocytes, e.g., directed diapedesis from the vascular space into the interstitium and the alveolar spaces, during inflammatory tissue responses is highly potentiated by IL-8 ${ }^{(35-37)}$. Therefore, diminished IL-8 cytokine levels induced by treatment with oxatomide might be of value with respect to reduced neutrophilic infiltration rates ${ }^{(38)}$ and decreased levels of activation of neutrophils ${ }^{(39)}$. In this study, we analyzed the oxatomide-dependent inhibition of IL-8 release from human respiratory cells (A549 cells) and from primary human nasal epithelial cells HNECs. Results of RT-PCR indicated that both A549 
cells and HNECs express TLR2 and TLR6. A549 cells expressed TLR4, but HNECs did not. Recently, bacterial components have been reported to stimulate cells via TLR2, TLR4 and TLR9. Neither HNECs nor A549 cells expressed TLR9. Lipoprotein, as a TLR2 and TLR6 agonist, promoted IL-8 production by epithelial cells, though lipid A, as a TLR4 agonist, did not enhance IL-8 production by epithelial cells, including A549 cells, which expressed TLR4 mRNA. These results indicate that lipoprotein stimulated nasal epithelial cells mainly via TLR2. TLR2 may act as a essential role of immunological responses on upper respiratory cells.

Next, we assessed the role of oxatomide in the production of IL-8 stimulated by lipoprotein. Pretreatment of the cells with oxatomide significantly diminished lipoprotein-induced IL-8 release from $A 549$ cells and HNECs. It was also found in the present study by luciferase assays and western blot analysis that lipoprotein induces IL-8 production and NF- $\mathrm{KB}$ activation in A549 cells and HNECs. The 5 '-flanking regions of genes coding for IL-8 contain putative binding sites for the transcription

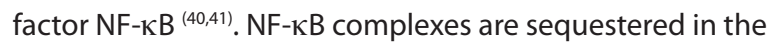
cytoplasm by inhibitory molecules, named $\operatorname{I\kappa } \mathrm{B} \alpha^{(42)}$. Upon cell stimulation with cytokines or viruses, I $\mathrm{KB} \alpha$ become degraded by phosphorylation on two serine residues at positions 32 and 36 , allowing migration of activated NF- $\mathrm{KB}$ into the nucleus and binding to the DNA-NF- $\kappa B$ binding site ${ }^{(43)}$. Pretreatment with oxatomide results in inhibition of the phospholylation of $І \kappa B \alpha$ as shown by Western blot analysis. From the luciferase assay, $\mathrm{NF}-\kappa \mathrm{B}$ activation was also inhibited by addition of oxatomide in a dose- dependent manner. These data indicates that oxatomide inhibited the IL-8 production from nasal epithelial cells stimulated with lipoprotein mainly via TLR2, by down-regulating the NFkB activity.

Finally, we analyzed the in vivo role of oxatomide using a murine acute rhinitis model. Interestingly, i.g. inoculation of oxatomide resulted in inhibition of nasal skin inflammation and neutrophil infiltration in the nasal membrane. Furthermore, expression of the murine chemokine MIP-2, a functional homologue of human IL-8, was also inhibited in the nasal membranes of mice i.g. inoculation with oxatomide. These in vivo data confirm the actual inhibitory effect of oxatomide on inflammatory reaction in nasal mucosal linings.

\section{Conclusion}

In conclusion, our results suggest that a TLR2 ligand mainly acts on respiratory epithelial cells and stimulates IL-8 production via $\mathrm{NF}-\kappa \mathrm{B}$ activation. Oxatomide clealy inhibited NF- $\mathrm{KB}$ activation and IL-8 production. Using a murine acute rhinitis model, we confirmed the in vivo inhibitory role of oxatomide in MIP-2 expression, a functional homologue of human IL-8, and neutrophil infiltration of the nasal membrane. There has been accumulating data on the immunomodulating in vitro effect of antihistamines in previous reports ${ }^{(44-46)}$. This anti-inflammatory potential of oxatomide, so called second generation of antihistamine, might be of great value for the treatment of inflammatory reaction in the upper respiratory tract, including acute rhinitis.

\section{Authorship contribution}

HK made this project and supervised all experimental processes with his immunological background and as otorhinolaryngologist. NA, IM, TF, YS, KS, YH, and QI have done all experiments together and produced data under the supervision of HK. TY mainly took care of animal experiments, based on his background as vetenarian. EP supervised all experiments from clinical point of view and gave us supervision of writing this article in English.

\section{Conflict of interest}

All authors declare that they have no conflict of interest or funding.

\section{References}

1. Juniper EF, Cartier A, Trebilcock AL, Frith PA, Dolovich J, et al. Effects of oxatomide compared with chlorpheniramine in allergic rhinoconjunctivitis. Clin Allergy. 1981; 11: 61-66.

2. Richards DM, Brogden RN, Heel RC, Speight TM, Avery GS. Oxatomide. A review of its pharmacodynamic properties and therapeutic efficacy. Drugs. 1984; 27: 210-231.

3. Marone G, Granata F, Spadaro G, Onorati AM, Triggiani M. Antiinflammatory effects of oxatomide. J Investig Allergol Clin Immunol. 1999; 9: 207-214.

4. Noma T, Yoshizawa I, Kawano Y, Nakajima T. Effect of oxatomide on T-cell activation and the production of interferon-gamma in mite sensitive asthma. Eur J Pharmacol. 1998; 343: 239-247.

5. Chihara J, Sugihara R, Kubo H, Yamamoto
T, Nakano $N$, et al. The inhibitory effect of oxatomide, an anti-allergic agent, on eosinophil-mediated and eosinophilic cel line-mediated natural cytotoxicity against bronchial epithelial cells. Arerugi. 1989; 38 1180-1184.

6. Ohmori K, Manabe H, Akuta-Ohnuma K Inhibitory effect of oxatomide on oxygenradical generation and peptide-leukotriene release from guinea pig eosinophils. Arzneimittelforschung. 1998; 48: 43-46.

7. Patella $V$, de Crescenzo G, Marino $O$ Spadaro G, Genovese A, et al. Oxatomide inhibits the release of proinflammatory mediators from human basophils and mast cells. Int Arch Allergy Immunol. 1996; 111: 23-29.

8. Tanaka T, Kurono Y, Kawauchi H, Mogi G. Effect of oxatomide on otitis media with effusion--an experimental study. Acta
Otolaryngol. 1995; 115: 532-538.

9. Pilewski JM, Sott DJ, Wilson JM, Albelda SM ICAM-1 expression on bronchial epithelium after recombinant adenovirus infection. Am J Respir Cell Mol Biol 1995; 12: 142-148.

10. Arnold R, König W. ICAM-1 expression and low molecular weight G-protein activation of human bronchial epithelial cells (A549) infected with RSV. J Leuk Biol 1996; 60: 776781

11. Devalia JL, Campbell AM, Sapsford RJ. Effect of nitrogen dioxide on synthesis of inflammatory cytokines expressed by human bronchial epithelial cells in vitro. Am J Respir Cell Mol Biol 1993; 9: 271-278.

12. Arnold R, Humbert B, Werchau H, Gallati $H$, König W. Interleukin-8, interleukin-6, and soluble tumour necrosis factor receptor type I release from a human pulmonary epithelial cell line (A549) exposed to res- 
piratory syncytial virus. Immunol 1994; 82 126-133.

13. Baggiolini M, Dewald B, Moser B. Interleukin-8 and related chemotactic cytokines CXC and CC chemokines. Adv Immunol 1994; 55: 97-179.

14. Larsen CG, Anderson AO, Appella E, Oppenheim JJ, Matsushima K. The neutrophil-activating protein (NAP-1) is also chemotactic for T lymphocytes. Science 1989; 249: 1464-1466.

15. Baggiolini M, Walz A, Kunkel SL. Neutrophilactivating peptide-1/interleukin 8 , a nove cytokine that activates neutrophils. J Clin Invest 1989; 84: 1045-1049.

16. Harada A, Sekido N, Akahoshi T, Wada T, Mukaida $N$, et al. Essential involvement of interleukin-8 (IL-8) in acute inflammation. J Leuk Biol 1994; 56: 559-564.

17. Oishi K, Sonoda F, Kobayashi S. Role of interleukin-8 (IL-8) and an inhibitory effect of erythromycin on $\mathrm{IL}-8$ release in the airways of patients with chronic airway diseases. Infect Immun 1994; 62: 4145-4152.

18. Böyum, A. Isolation of mononuclear cells and granulocytes from human blood. Scand. J. Clin. Lab. Investig 1968; 97: 77-89.

19. Brightbill HD, Libraty DH, Krutzik SR, Yang RB, Belisle JT, et al. Host defense mechanisms triggered by microbial lipoproteins through toll-like receptors. Science 1999; 285: 732-736.

20. Cario E, Rosenberg I M, Brandwein SL, Beck $\mathrm{PL}$, Reinecker $\mathrm{HC}$, et al. Lipopolysaccharide activates distinct signaling pathways in intestinal epithelial cell lines expressing Toll-like receptors. J. Immunol 2000; 164: 966-972.

21. Takeuchi O, Hoshino K, Kawai T, Sanjo $H$,

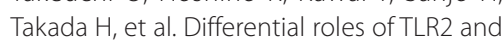
TLR4 in recognition of gram-negative and gram-positive bacterial cell wall components. Immunity. 1999; 11: 443-451.

22. Schwandner $R$, Dziarski $R$, Wesche $H$, Rothe M, Kirschning CJ. Peptidoglycan- and lipoteichoic acid-induced cell activation is mediated by toll-like receptor 2. J Biol Chem. 1999; 274: 17406-17409.

23. Imasato A, Desbois-Mouthon C, Han J, Ka $\mathrm{H}$, Cato AC, et al. Inhibition of p38 MAPK by glucocorticoids via induction of MAPK phosphatase-1 enhances nontypeable Haemophilus influenzae-induced expres sion of toll-like receptor 2. J Biol Chem. 2002; 277: 47444-47450.

24. Lieber M, Smith B, Szakal A, Nelson-Rees W Todaro G. A continous tumor-cell line from a human lung carcinoma with properties of type II alveolar epithelial cells. Int J Cancer 1976; 17: 62-70.

25. Chomczynski P, Sacchi N. Single-step method of RNA isolation by acid guanidium thiocyanate-chloroform extraction. Anal. Biochem 1987; 162: 156-159.

26. Ishimitsu R, Yajima T, Nishimura H, Kawauchi
$H$, Yoshikai Y. NKT cells are dispensable in the induction of oral tolerance but are indispensable in the abrogation of oral tolerance by prostaglandin E. Eur J Immunol. 2003; 33: 183-193.

27. Dilworth D, McCarrey JR. Single-step elimination of contaminating DNA prior to reverse transcriptase PCR. PCR Methods Appl 1992; 1: 279-282.

28. Ishimitsu R, Nishimura H, Yajima T, Watase T, Kawauchi $H$, Yoshikai Y. Overexpression of IL-15 in vivo enhances Tc1 response, which inhibits allergic inflammation in a murine model of asthma. J Immunol. 2001; 166: 1991-2001.

29. Ishimitsu R, Nishimura $H$, Kawauchi $H$, Kawakita T, Yoshikai Y. Dichotomous effect of a traditional Japanese medicine, buzhong-yi-qi-tang on allergic asthma in mice. Int Immunopharmacol. 2001; 1: 857 865

30. Liu S, Gallo DJ, Green AM, Williams DL, Gong $X$, et al. Role of toll-like receptors in changes in gene expression and NF-kappa B activation in mouse hepatocytes stimulated with lipopolysaccharide. Infect Immun. 2002; 70: 3433-3442.

31. Bernasconi NL, Onai N, Lanzavecchia A. A role for Toll-like receptors in acquired immunity: up-regulation of TLR9 by BCR triggering in naive $B$ cells and constitutive expression in memory B cells. Blood. 2003; 101: 4500-4504.

32. Ohyama Y, Nakamura S, Matsuzaki G, Shinoharam M, Hiroki A, et al. Cytokine messenger RNA expression in the labial salivary glands of patients with Sjögren syndrome. Arthritis Rheum 1996; 39: 1376-1384

33. Matsuguchi T, Zhao Y, Lilly MB, Kraft AS. The cytoplasmic domain of granulocytemacrophage colony-stimulating factor (GM-CSF) receptor subunit is essential for both GM-CSF-mediated growth and differentiation. J. Biol. Chem 1997: 272: 17450.

34. Matsuguchi T, Musikacharoen T, Ogawa T, Yoshikai Y. Gene Expressions of Toll-Like Receptor 2, But Not Toll-Like Receptor 4, Is Induced by LPS and Inflammatory Cytokines in Mouse Macrophages1. J Immunol, 2000, 165: 5767-5772.

35. Detmers PA, Lo SK, Olsen-Egbert E, Walz A, Baggiolini $M$, et al. Neutrophil-activating protein 1 /interleukin-8 stimulates the binding activity of the leukocyte adhesion receptor CD11b/CD18 on human neutrophils. J Exp Med 1990; 171: 1155-1162.

36. Smith WB, Gamble JR, Clark-Lewis I, Vadas MA. Chemotactic desensitization of neutrophils demonstrates interleukin-8 (IL-8) -dependent and IL-8-independent mechanisms of transmigration through cytokineactivated endothelium. Immunol 1993; 78 : 491-497.

37. Madara JL. Migration of neutrophils through epithelial monolayers. Trends Cell
Biol 1994; 4: 4-7

38. Bellini A, Yoshimura $H$, Vittori $E$, Marini M, Mattoli S. Bronchial epithelial cells of patients with asthma release chemoattractant factors for T lymphocytes. J Allergy Clin Immunol 1993; 92: 412-424.

39. Chomczynski P, Sacchi N. Single step method for RNA isolation by acid guanidinium thiocyanate-phenol-chloroform extraction. Anal Biochem 1987; 162: 156-159.

40. Voraberger G, Schafer R, Strotowa C. Cloning of the human gene for intercellular adhesion molecule-1 and analysis of its 5'-regulatory region. J Immunol 1991; 147: 2777-2783.

41. Mukaida N, Okamoto S, Ishikawa Y, Matsushima K. Molecular mechanism of interleukin-8 gene expression. J Leuk Biol 1994: 56: 554-558.

42. Barnes PJ, Karin M. Nuclear factor-kB: a pivotal transcription factor in chronic inflammatory diseases. N Engl J Med 1997; 336: 1066-1071.

43. DiDonato JA, Hayakawa M, Rothwarf DM, Zandi E, Karin M. A cytokine-responsive IkB kinase that activates the transcription factor NF-kB. Nature 1997; 388: 548-554.

44. Shoji N, Asano K, Furuta A, Hirano K, Suzaki $\mathrm{H}$. Effect of histamine $\mathrm{H} 1$ receptor antagonists on TARC/CCL17 and MDC/CCL22 production from CD14+ cells induced by antigenic stimulation in vitro. Int Arch Allergy Immunol. 2011;155(1):38-51.

45. Asano K, Kanai K, Suzaki H. Suppressive activity of fexofenadine hydrochloride on thymus- and activation-regulated chemokine production from human peripheral blood leukocytes in response to antigenic stimulation in vitro. Int Arch Allergy Immunol. 2004;133(3):267-75.

46. Okamoto T, Iwata S, Ohnuma K, Dang NH, Morimoto C. Histamine $\mathrm{H} 1$-receptor antagonists with immunomodulating activities: potential use for modulating $T$ helper type 1 (Th1)/Th2 cytokine imbalance and inflammatory responses in allergic diseases. Clin Exp Immunol. 2009 Jul;157(1):27-34.

Hideyuki Kawauchi

Dept. of Otorhinolaryngology

Shimane University

Faculty of Medicine

Izumo City, 693-8501

Japan

Tel: +81-853-20-2273

Fax: +81-853-20-2271

E-mail:

kawauchi@med.shimane-u.ac.jp 